\title{
Students' Attitudes towards the Adoption of International Financial Reporting Standards (IFRS) in Kuwait
}

\author{
Abdullah AL-Mutairi ${ }^{1}$, Kamal Naser ${ }^{2}$, Nabi Al-Duwaila ${ }^{3}$ \\ ${ }^{1}$ Gulf University for Science and Technology, Kuwait \\ ${ }^{2}$ Financial and Economic Advisor, Kuwait Fund, Kuwait \\ ${ }^{3}$ Public Authority for Applied Education and Training (PAAET), Kuwait \\ Correspondence: Abdullah AL-Mutairi, Gulf University for Science and Technology, Kuwait. E-mail: \\ mutairi.a@gust.edu.kw
}

Received: February 22, 2017

Accepted: March 30, 2017

Online Published: April 19, 2017

doi:10.5539/ass.v13n5p85

URL: https://doi.org/10.5539/ass.v13n5p85

\begin{abstract}
The purpose of this paper is to examine the perceptions of a sample of Kuwaiti students about their knowledge and interest on the adoption of International Financial Reporting Standards (IFRS) and the usefulness of learning IFRS. A questionnaire survey is used in this study to identify the attitudes of the students towards adoption IFRS in Kuwait. Questionnaires were distributed to 350 students who study in colleges of business administration in Kuwait. They were asked to express their perception about the adoption of IFRS. 228 questionnaires returned completed resulting in $65 \%$ usable response rate. The surveyed students gained knowledge about IFRS through their academic program. Most of the surveyed students knew nothing about IFRS before taking an accounting course that addresses the IFRS Standards. They became interested in learning more about IFRS after studying an accounting course. The surveyed students demonstrated that they acquired information about IFRS through formal academic lectures and the Internet. Yet, they prefer to study more about IFRS through formal lectures, practical case studies applied to Kuwaiti companies and seminars. There is consensus among the respondents that the business administration academic program must have more about IFRS offered as elective courses. Although Kuwait was one of the Middle Eastern countries that adopt IFAS, the vast majority of the students who took part in survey indicated that they were not aware of this. This gives clear indication that the financial reporting courses offered in business colleges in Kuwait are theoretical and hardly use the financial reports of companies listed on the national stock exchange as cases studies. The respondents believe studying IFRS helps in mastering accounting measurements and disclosure and this would help in proceeding in their studies and support them in developing their future career.
\end{abstract}

Keywords: IFRS adoption, students' attitudes, Accounting quality, Kuwait

\section{Introduction}

The adoption of International Financial Reporting Standards (IFRS) has been subject of growing theoretical and empirical investigation in accounting literature. The main issue of the literature is to explore the impact of cultural factors such as religion, national satisfaction, language, accounting requirements that may affect regulators' decision to embrace IFRS. Research into the perception of stakeholders towards the adoption of IFRS has shown inclusive evidence. While in one hand, it is found that adopting IFRS might lead to high financial cost, in the other, evidence revealed that the adoption of IFRS results in several benefits such as decreased cost of capital and attraction of foreign direct investment. There is further evidence that students' familiarity with IFRS would assist them passing professional examinations and in their future career development.

These findings, however, seems to be questionable for the highly oil-dependent countries such as the Gulf Co-operation Council (GCC) which rely more heavily on fiscal rather than monetary policy to stimulate the economy. Oil exporting countries have tremendous revenue, they do not suffer from any liquidity problem, and they have no incentive to attract foreign investment. In this context, understanding students' perceptions about the adoption of IFRS can be of interest for business schools operating in GCC countries. It helps them in developing accounting curriculum integrated with IFRS and providing high-quality education to business students. 
The remainder of this study is organized as follows. A brief review of related literature and previous studies are presented in the next section. Data collection and research method are considered in the third section. While the findings and analysis are discussed in the fourth section, the conclusion is offered in the last section.

\section{Related Literature and Previous Studies}

IFRS is a set of international accounting standards aim to create good communication between company's management and its stakeholders. The adoption of IFRS leads to accurate, timely and comprehensive financial statements in line with the national standards (Madawaki, 2012). Investors expected to pay less for adjusting financial statements and will be able to understand them and reduce the cost of finalizing them (Odia \& Ogiedu, 2013). The extent of compliance of IFRSs insures financial reporting reliability and accuracy (Hossain, Niaz \& Moudud-Ul-Huq, 2015a). According to Papadatos and Bellas (2011), adopting IFRS increases credibility and transparency of financial statements. It further contributes to the market efficiency. However, Naghshbandi, Ombati, and Khosravi, (2016) contend that culture seems to affect the level of information disclosed, through accounting value secrecy on the IFRS practices. Be as it may, accounting standards are a product of the country's culture.

Although the theoretical justifications for replacing national accounting standards by IFRS, their adoption still needs to be empirically tested. Attitudes towards the adoption of IFRS have been examined in various countries (see for example, Grrece: Papadatos and Bellas, 2011; Dritsas and Petrakos, 2014; Nigeria: Madawaki, 2012; Ikpefan and Akande, 2012; Odia and Ogiedu, 2013; Herbert, Tsegba, Ohanele, and Anyahara, 2013; Herbert and Tsegba, 2013; Okunbor and Arowoshegbe, 2014; Malaysia: Sidik and Abd Rahim, 2012; Hanefah and Singh, 2012; India: Patro and Gupta, 2012; Athma and Rajyalaxmi, 2013; Bhargava and Shikha, 2013; Vinayagamoorthy, 2014. USA: Djatej, Zhou, Gorton, and McGonigle, 2012; Joos and Leung, 2013; Hong Kong: Helen and Kh, 2013; Ghana: Mensah, 2013; Abedana, Omane-Antwi, and Oppong, 2016; Turkey: Chebaane and Othman, 2013; Balsari and Varan, 2014; Kılıça, Uyar and Ataman, 2014; Vietnam: Phan, Mascitelli, and Barut, 2014. Libya: Zakari, 2014; Bangladesh: Hossain et al., 2015a; Hossain, Hasan,and Safiuddin, 2015b; Australia: Bodle, Cybinski, \& Monem, 2016). These studies are briefly reviewed in the following section.

Papadatos and Bellas (2011) examined the attitude of listed companies towards mandatory adoption of IFRS in Greece. They found small firms and low-income firms have negative attitude towards IFRS. They also found firms with higher level of fixed assets to be more optimistic about the benefits of IFRS to investors. In a related type of research, Dritsas and Petrakos (2014) studied whether significant differences exist between the IFRS and the Greek General Accepted Accounting Principles. They noticed that converting statutory financial statements to IFRS has significant impact on historical financial information regarding financial structure and viability.

Madawaki (2012) examined the process of adopting IFRS in Nigeria. He pointed to potential benefits of assuming IFRS related to assurance of useful and meaningful investment portfolio decisions and the attraction of direct foreign investment. He recommended creating an independent body to set, monitor and enforce accounting and auditing standards and codes. In a similar line of research and the same country, Ikpefan and Akande (2012) examined the benefits of adopting IFRS. He observed adopting IFRS results in greater comparability of financial information for investors due to transparent financial reporting of company's activities and greater willingness on the part of investors to invest across borders. Odia and Ogiedu (2013) also examined the adoption of IFRS in Nigeria and found countries face cultural, language, regulatory and accounting profession challenges when adopting IFRS. They believe that effective implementation of IFRS requires careful planning and extensive public education as well as adequate resources to support their sustainable implementation. Herbert et al. (2013) further examined the perception of academics and practitioners towards the adoption of IFRS in Nigeria. They found significant differences between accounting students, lecturers and practitioners with respect to their degree of familiarity with IFRS. They also found Nigeria was not ready to adopt IFRS.

Herbert and Tsegba (2013) looked at IFRS from a different angle and studied the economic consequences of the adoption of IFRS in Nigeria. They think that effective IFRS adoption is valuable to preparers, users, auditors, analysts, and standard setters; and a proper plan to convert all Nigerian companies to IFRS requires training for management, auditors, and investors, along with the pipeline incorporation of IFRS education into accounting curriculum. Okunbor and Arowoshegbe (2014) added that significant differences exist in the perceptions of stakeholders regarding the effect of adopting IFRS on the value of financial reports. They emphasized the need to develop an awareness program to highlight the importance of adopting and implementing IFRS in Nigeria.

Sidik and Abd Rahim (2012) used a questionnaire survey to explore the benefits and challenges IFRS in Malaysia from accounting practitioners perspectives. They found the adoption of IFRS improves comparability level between companies' financial statements since they are prepared using a better standard. They also found 
that the majority of the respondents believe that the introduction of the IFRS might lead to higher financial cost. Hanefah and Singh, (2012) investigated challenges faced Malaysia as a result of adopting IFRS. They uncovered challenges to standard-setters and stakeholders need to enhance cross-border comparability of Islamic financial transactions, while being mindful of religious sensitivities. They concluded that Malaysian education system is very much in line with the current developments in the accounting and business fraternity.

Patro and Gupta (2012) examined the adoption of IFRS in accounting curriculum in India. They found the successful integration to the course depends upon efficient training of instructors, use of appropriate pedagogy and availability of relevant reading materials. Also, Athma and Rajyalaxmi (2013) examined the adoption of IFRS in India. They found the adoption of IFRS enhances comparability between the financial statements of various companies across the globe and reduces different accounting requirements prevailing in various countries. They also found that the adoption of IFRS provides a chance to integrate with the common Accounting International Standards. A similar study conducted in India by Bhargava and Shikha (2013) disclosed that adopting IFRS improves quality of disclosures and enhances international comparability and understanding of financial statements. Vinayagamoorthy (2014) tested the benefits from adopting IFRS in India and found that it assists in attracting greater cross-border investment and presenting financial statement on a single set of high quality and global standards.

Djatej et al. (2012) used Planned Behavior Theory to identify a wide variety of relevant factors influencing the intention of early implementation of IFRS in United States. They showed that an accountant's decision to adopt IFRS is a function of subjective norm and perceived behavioral control, which is consistent with the theory. Joos and Leung (2013) examined whether investors perceive the switch to IFRS as being beneficial or costly. They reported that investors' reaction to IFRS adoption is more positive in cases where IFRS is expected to lead to convergence benefits.

Helen and Kh (2013) examined students' knowledge and interest in adopting IFRS and the usefulness of learning IFRS in Hong Kong. They found most Hong Kong students are eager to learn IFRS and they understand the positive effect of learning IFRS. They also observed that students' knowledge of IFRS would help them in their professional examinations and future career development. They advised accounting professionals and education providers to develop materials on IFRS.

Mensah (2013) examined the quality of financial reports of firms listed on the Ghana Stock Exchange before and after adopting IFRS. He found that company size, represented by net assets and auditor type are statistically associated with the quality of financial information disclosed. He observed that big firms audited by big audit firms tend to produce high quality accounting reports. Another more recent study undertaken in Ghana by Abedana et al. (2016) examined the impact of adopting IFRS on the quality of corporate financial reporting found a significant positive correlation between the disclosure quality of listed firms and the adoption of IFRSs. They concluded that companies wishing to make quality disclosure should continue to comply with the IFRSs rigorously.

Chebaane and Othman (2013) considered the impact of IFRS adoption on the frequency of earnings managements towards small positive profits. They found that mandatory IFRS adoption in Turkey reduce the scope of earnings management towards small positive profits in the post-adoption periods. Balsari and Varan (2014) looked at the application of IFRS in Turkey and established that both businessmen and accountants showed resistance despite professional accounting body and academia support to IFRS adoption. The researchers also found major impact of IFRS on financial statement analysis. Kıliça et al. (2014) gathered the perception of the accounting professionals regarding IFRS for small and medium-sized enterprises (SMEs). They detected that most of the accounting professionals are aware of IFRS for SMEs adoption process and attended trainings programs about IFRS for SMEs. They also noticed that lack of training and costs are seen as the main obstacles to the IFRS for SMEs implementation.

Phan et al. (2014) pursued the perceptions of public auditors, corporate accountants and accounting academics about issues relevant to adopting and implementing IFRS in Vietnam. They found Vietnamese accounting professionals are optimistic about potential benefits from IFRS adoption. They strongly supported gradual switch from Vietnamese accounting standards (VAS) to IFRS, though the level of support varies amongst the three different sub-groups of accountants.

Zakari (2014) used a questionnaire survey to locate challenges that face implementing of IFRS by Libyan firms. He found the majority of who took part in the survey agreed that the weakness of national professional accountancy body is main challenge facing IFRS adoption by Libyan companies. He also found lack of technical skills and inadequate knowledge of Libyan professional accountants have major impact on IFRS implementation. 
The researcher believes that developing Libyan legislation, professional bodies and accounting education could help in the adoption of IFRS.

Hossain et al. (2015a) examined the extent of application and disclosure of IFRSs among the listed companies in Dhaka Stock Exchange (DSE) of Bangladesh. They found financial institution and insurance industries applied and complied with the highest number of IFRSs. They proposed that the company should employ professional expertise to measure and valuate certain assets where it needs proper disclosure. Hossain et al.; (2015b) examined recent adoption status of IFRS in Bangladesh. They indicated that IFRS adoption promises a lot of benefits like decreased cost of capital, improved financial reporting quality and attraction of foreign direct investment. They also found that there are a lot of technical Challenges faced by the users while adopting IFRSs such as lot of conflicts with local GAAP.

Bodle et al. (2016) examined the impact of IFRS adoption on financial reporting quality by assisting in predicting bankruptcy. They found that restrictive accounting rules for intangibles under IFRS improve the quality of financial statement data by enabling better bankruptcy prediction. They provided evidence to support the notion that new conservative rules for intangibles under IFRS act to constrain managers of failing firms from using creative accounting practices.

As far as the GCC region is concerned, few studies used a questionnaire survey to examine the adoption of IFRS (see for example, Kuwait: Al Mutawaa and Hewaidy, 2010; Saudi Arabia: Alsuhaibania, 2012; Bahrain: Sarea and Al Nesuf, 2013; UAE: Alsaqqa and Sawan, 2013; Qatar: Mardini and Almujamed, 2015). The following section offers a brief review of these studies.

Al Mutawaa and Hewaidy (2010) surveyed the extent of Kuwaiti listed companies' compliance with the International Accounting Standards (IAS)/IFRSs disclosure requirements. The overall compliance level for the sampled companies averages $69 \%$ of the disclosures required by the standards tested. They also found company size and industry type to be positively associated with IAS-required disclosures.

Alsuhaibania (2012) looked into the expected impact of IFRS adoption in Saudi Arabia. He found the adoption of IFRS enhances financial reporting in Saudi Arabia and provides more information for decision making. He also found that the adoption of IFRS has some cultural impact, especially on issues related to the Islamic aspects in the Saudi financial sector. He concluded that the telecommunication sector is expected to be one of the main sectors that are affected by such adoption.

Sarea and Al Nesuf (2013) assessed the impact of management structure and bank characteristics on the level of compliance with IAS 21 in Bahrain Stock Exchange (BSE). They found that there is an impact of the management structure and bank characteristics on the level of compliance with IAS 21 in Bahrain. They also found that institutional ownership, foreign investments, return on assets and return on equity have significant and positive relationship with the level of compliance with IAS 21. The researchers observed that banks of Bahrain have a high level of compliance with IAS 21 standard.

Alsaqqa and Sawan (2013) looked into the benefits gained and the challenges experienced by companies listed on the UAE stock market following the introduction of IFRS. They found that the benefits of adopting IFRSs in UAE inevitably far outweigh the difficulties and costs. They also revealed that the adoption of IFRSs in UAE stock markets has improved the overall standard of quality of financial reporting, which help in attracting investors to invest in the UAE stock markets.

Mardini and Almujamed (2015) compared segmental information disclosures of Qatari companies under IFRS 8 for 2009 with disclosures under IAS 14R for 2008. They observed increase in segmental disclosures under IFRS 8 compared to the information published under IAS 14R. They also found that IFRS 8 compliance amongst Qatari listed companies has resulted in an increase in the number of segments and items per segment disclosed.

It is evident from the above brief literature review little research has been undertaken to examine students attitude towards the adoption of IFRS in Kuwait. This emphasizes the need for additional empirical testing. Hence, the contribution that this study will make is expected to fill the gap in the literature.

\section{Data Collection and Research Methodology}

The current study is based on primary data. During the period between September and December 2016, the researchers distributed a questionnaire to 350 students. 246 students returned the questionnaires; out of the 246 questionnaires, only 228 questionnaires were answered properly. This resulted in $65 \%$ a usable response rate. The questionnaires were then entered in an SPSS file for analysis. Cronbach's Alpha was used to measure the internal consistency of the collected data. Descriptive statistics have been employed to shed some light on the respondents and their attitude towards different aspects of IFRS. To identify possible differences in the 
respondents' answers to the questions included in the questionnaire, Kruskal Wallis U test was undertaken.

\section{Findings}

To measure the internal consistency (reliability) of the collected data, Cronbach's Alpha $(\alpha)$ was performed and touched 0.918. In general, a commonly acceptable Cronbach's Alpha $(\alpha)$ is $\geq 0.70$.

\subsection{Respondents Background}

Table (1) summarizes the main characteristics of the respondents who took part in the questionnaire. It can be witnessed in the table that $77 \%$ of the respondents are between $20-23$ years old, $88 \%$ of them are single and $57 \%$ are males. The table also showed that $81 \%$ of the respondents obtained between $61-80 \%$ score in the general secondary examination (GSE). The table further revealed that the surveyed students are fairly distributed among different categories of their last academic semester GPA. The diversity of the respondents, in terms of their personal backgrounds and academic performance, give credibility to the outcome of the study and provides strong ground to generalize Kuwaiti business students' opinion about different aspects of IFRS.

Table 1. Respondents' background

\begin{tabular}{ccc}
\hline Age & Frequency & Percent \\
\hline 18-19 Years Old & 28 & 12 \\
20-21 Years Old & 107 & 47 \\
22-23 Years old & 68 & 30 \\
24 Years or more & 25 & 11 \\
Total & 228 & 100 \\
\hline
\end{tabular}

\begin{tabular}{ccc}
\hline Marital Status & Frequency & Percent \\
\hline Single & 200 & 88 \\
Married & 28 & 12 \\
Total & 228 & 100
\end{tabular}

\begin{tabular}{ccc}
\hline Gender & Frequency & Percent \\
\hline Male & 131 & 57 \\
Female & 97 & 43 \\
Total & 228 & 100 \\
\hline & & \\
\hline Current Semester GPA & Frequency & Percent \\
\hline Less than 2.00 & 24 & 11 \\
Between 2.00- 2.49 & 28 & 12 \\
Between 2.50- 2.99 & 46 & 20 \\
Between 3.00- 3.49 & 78 & 34 \\
3.50 or more & 52 & 23 \\
Total & 228 & 100 \\
\hline
\end{tabular}

\subsection{Knowledge of IFRS}

Table (2) summarizes respondents' understanding of IFRS. To determine whether the surveyed students obtained some knowledge about IFRS through some work experience, they were asked if they work while they were studying. The vast majority of the respondents indicated that they do not work while studying. Hence, their knowledge about IFRS is mainly restricted to what they have learned in the college. Since the business administration program offers limited information about IFRS through some accounting courses, students were asked if they intend to proceed in their studies to assess whether this will motivate them to learn more about IFRS.

The table showed that $84 \%$ of the surveyed students are willing to proceed in their studies. In all cases, the table demonstrated that most of the surveyed students knew nothing about IFRS before taking an accounting course that addresses the IFRS. The respondents became interested to know more about IFRS after studying the accounting course. When the surveyed students were asked how they obtain information about IFRS, they pointed to several sources. However, the vast majority indicated that they obtain information about IFRS from the lectures and the Internet. Yet, when the surveyed students were asked how they prefer to study more about IFRS, they pointed to lectures and practical cases studies as the most important methods of teaching.

The surveyed students seem to prefer different methods of teaching including seminars. Although the surveyed students revealed that the accounting degree should include a course that covers IFRS, they, however, want the course to be offered as an elective course rather a compulsory course. They also believe there is a need to offer additional courses as elective. What attracts attention in Table (2) is the vast majority of the surveyed students are not aware that it is mandatory for all companies listed on Kuwait Stock Exchange to adopt IFRS. 
Table 2. Respondents current and future prospects and their understanding of IFRS

\begin{tabular}{ccc}
\hline Do you work while studying & Frequency & Percent \\
\hline Yes & 22 & 10 \\
No & 206 & 90 \\
Total & 228 & 100 \\
\hline Were you aware of IFRS before & Frequency & Percent \\
studying course 151 & & \\
\hline Yes & 39 & 17 \\
No & 189 & 83 \\
Total & 228 & 100 \\
\hline How are willing to study IFRS & Frequency & Percent \\
courses & 95 & 42 \\
\hline Lectures & 47 & 20 \\
Seminars & 75 & 33 \\
Companies & 11 & 5 \\
Others & 228 & 100 \\
Total & &
\end{tabular}

\begin{tabular}{ccc}
\hline $\begin{array}{c}\text { IFRS should a requirement course } \\
\text { for accounting major }\end{array}$ & Frequency & Percent \\
\hline Yes & 145 & 64 \\
No & 83 & 36 \\
Total & 228 & 100 \\
\hline
\end{tabular}

Are you aware that the State of

Kuwait was among the first countries to adopt IFRS and all companies on Kuwait Stock Exchange are obliged to employ these standards?

\begin{tabular}{ccc}
\hline Yes & 86 & 38 \\
No & 142 & 62 \\
Total & 128 & 100 \\
\hline
\end{tabular}

\begin{tabular}{ccc}
\hline $\begin{array}{c}\text { Are you willing to proceed in your } \\
\text { study }\end{array}$ & Frequency & Percent \\
\hline Yes & 192 & 84 \\
No & 36 & 16 \\
Total & 228 & 100 \\
\hline & & \\
\hline
\end{tabular}

\begin{tabular}{ccc}
\hline $\begin{array}{c}\text { You became interested in studying } \\
\text { IFRS after you had studied course } \\
151\end{array}$ & Frequency & Percent \\
\hline Yes & 168 & \\
No & 60 & 26 \\
Total & 228 & 100 \\
\hline
\end{tabular}

\begin{tabular}{ccc}
\hline $\begin{array}{c}\text { How you obtain information } \\
\text { about IFRS }\end{array}$ & Frequency & Percent \\
\hline $\begin{array}{c}\text { Newspapers } \\
\text { Magazines }\end{array}$ & 20 & 9 \\
Lectures & 18 & 8 \\
Training courses & 100 & 44 \\
Internet & 15 & 6 \\
Others & 65 & 29 \\
Total & 10 & 4 \\
\hline Additional courses in IFRS should & Frequency & Percent \\
be & 64 & 28 \\
\hline Compulsory & 164 & 72 \\
Elective & 228 & 100 \\
Total & & \\
\hline
\end{tabular}

Are you willing to take more specialized courses in the field of IFRS

Frequency Percent

\subsection{Important Role of the IFRS}

Table (3) summarizes respondents' assessment of the importance of learning IFRS. They were asked to disclose how learning IFRS is important to different aspects of corporate reporting. Although the respondents appeared to attach high importance to all listed aspects of financial reporting as reflected by the reported means and medians, they considered IFRS of paramount importance in recording business financial transactions, preparing a report about corporate performance and financial position, preparing final financial statements and in comparing performance and financial positions of different companies. The respondents do not seem to assign the same levels of importance to other aspects of corporate financial reporting included in the questionnaire.

This result can be explained on the ground that IFRS are very important in the accounting process. Their role is mainly restricted to accounting measurements and disclosure. In addition, adopting them in different countries assists international investors in making sound comparison between companies operating in different countries. They expect these countries to follow the same measurements and to have the same disclosure (presentation). In other words, adopting IFRS offer a common language for investors all over the world. Given that Kuwait has one of the highest per capita in the world, Kuwaitis are investing in companies operating in different parts of the world. Understanding IFRS helps in choosing between different investments alternatives.

Other aspects of financial reporting included in the questionnaire received less importance since they are not 
directly related to accounting measurements and disclosure. For instance, financial statement analysis is used in making investment and managerial decisions. Hence, IFRS are not considered important in either conducting the analysis or in making decisions.

Table 3. The importance of IFRS to different aspects of corporate financial reporting

\begin{tabular}{|c|c|c|c|c|c|c|}
\hline Aspects of corporate reporting & Mean & Median & $\begin{array}{l}\text { Std. } \\
\text { Devi. }\end{array}$ & Min. & Max. & $\begin{array}{l}\text { Rank based } \\
\text { on the mean }\end{array}$ \\
\hline Recording business financial transactions & 4.20 & 4 & 0.76 & 2 & 5 & 1 \\
\hline $\begin{array}{l}\text { Preparing final financial statements (Income Statement, Balance } \\
\text { Sheet and Statement of Cash Flows }\end{array}$ & 4.15 & 4 & 0.80 & 2 & 5 & 3 \\
\hline $\begin{array}{l}\text { Preparing a report about corporate performance and financial } \\
\text { position }\end{array}$ & 4.17 & 4 & 0.84 & 1 & 5 & 2 \\
\hline Analysing final financial statements & 4.08 & 4 & 0.84 & 2 & 5 & 5 \\
\hline $\begin{array}{l}\text { Making decisions related to operating, financial and investment } \\
\text { activities }\end{array}$ & 4.02 & 4 & 0.89 & 1 & 5 & 7 \\
\hline Making managerial decisions & 3.98 & 4 & 0.89 & 1 & 5 & 8 \\
\hline Project and enterprise management & 4.05 & 4 & 0.82 & 1 & 5 & 6 \\
\hline $\begin{array}{l}\text { Comparing performance and financial positions of different } \\
\text { companies }\end{array}$ & 4.09 & 4 & 0.91 & 1 & 5 & 4 \\
\hline
\end{tabular}

To detect differences among the respondents about the importance they attach IFRS role in different aspects of corporate financial reporting, Kruskal Wallis test was performed and reported in table (4). The table shows consistency among the respondents regardless of their age, gender, GSC score, whether they work or not they work while studying and whether or not they intend to proceed in their studies. Two significant differences reported among the respondents as on the basis of the GPA about the importance of IFRS in preparing a report about corporate performance and financial position and in analysing the final financial statements. These two significant differences are mainly due to those who attached highly important and important as they accounted to more than $80 \%$ of the respondents' answers.

Table 4. Kruskal Wallis test on difference among students about the importance of IFRS

\begin{tabular}{|c|c|c|c|c|c|c|c|c|c|c|c|c|}
\hline \multirow[t]{2}{*}{ Advantages } & \multicolumn{2}{|c|}{ Age } & \multicolumn{2}{|c|}{ Gender } & \multicolumn{2}{|c|}{ GSC Score } & \multicolumn{2}{|c|}{ GPA } & \multicolumn{2}{|c|}{$\begin{array}{l}\text { Work while } \\
\text { studying }\end{array}$} & \multicolumn{2}{|c|}{$\begin{array}{l}\text { Proceed in } \\
\text { your studies }\end{array}$} \\
\hline & $\mathrm{X}^{2}$ & Sig. & $\mathrm{X}^{2}$ & Sig. & $\mathrm{X}^{2}$ & Sig. & $\mathrm{X}^{2}$ & Sig. & $\mathrm{X}^{2}$ & Sig. & $\mathrm{X}^{2}$ & Sig. \\
\hline Recording business financial transactions & 2.64 & 0.45 & 0.02 & 0.88 & 4.78 & 0.31 & 2.35 & 0.67 & 0.07 & 0.80 & 0.03 & 0.18 \\
\hline $\begin{array}{l}\text { Preparing final financial statements (Income } \\
\text { Statement, Balance Sheet and Statement of } \\
\text { Cash Flows }\end{array}$ & 2.63 & 0.45 & 0.01 & 0.94 & 5.21 & 0.27 & 7.70 & 0.10 & 0.74 & 0.39 & 0.87 & 0.67 \\
\hline $\begin{array}{l}\text { Preparing a report about corporate } \\
\text { performance and financial position }\end{array}$ & 2.38 & 0.50 & 0.15 & 0.70 & 3.78 & 0.44 & 12.09 & 0.02 & 0.76 & 0.38 & 0.03 & 0.18 \\
\hline Analysing final financial statements & 1.59 & 0.66 & 0.64 & 0.42 & 4.51 & 0.34 & 10.37 & 0.04 & 0.09 & 0.77 & 0.87 & 0.67 \\
\hline $\begin{array}{l}\text { Making decisions related to operating } \\
\text { financial and investment activities }\end{array}$ & 1.15 & 0.76 & 0.15 & 0.70 & 4.70 & 0.32 & 1.52 & 0.82 & 4.07 & 0.04 & 0.03 & 0.18 \\
\hline Making managerial decisions & 2.08 & 0.56 & 0.02 & 0.90 & 4.36 & 0.36 & 0.93 & 0.92 & 0.90 & 0.34 & 0.87 & 0.67 \\
\hline Project and enterprise management & 1.38 & 0.71 & 0.00 & 0.97 & 4.53 & 0.34 & 1.99 & 0.74 & 1.04 & 0.31 & 0.03 & 0.18 \\
\hline $\begin{array}{l}\text { Comparing performance and financial } \\
\text { positions of different companies }\end{array}$ & 1.75 & 0.63 & 0.55 & 0.46 & 3.99 & 0.41 & 3.52 & 0.48 & 0.02 & 0.90 & 0.87 & 0.67 \\
\hline
\end{tabular}

\subsection{Reasons behind Studying IFRS}

Table (5) encompassed possible reasons why Kuwaiti students need to study IFRS. Students were asked to identify to what extent they agree or disagree with each of these reasons. It is clear from the table that the surveyed students either agreed or strongly agreed with the listed reason as reflected by the reported means and medians. However, the surveyed students believe that studying IFRS will help them to proceed with their studies and assist them in finding jobs in one of the big companies in the future. They further believe that since all Kuwaiti companies listed on the stock exchange adopt IFRS, this necessities studying and understanding IFRS in order to develop their future career. 
Table 5. Reasons behind studying IFRS

\begin{tabular}{|c|c|c|c|c|c|c|}
\hline Reasons & Mean & Median & $\begin{array}{l}\text { Std. } \\
\text { Devi. }\end{array}$ & Min. & Max. & $\begin{array}{l}\text { Rank based } \\
\text { on the mean }\end{array}$ \\
\hline $\begin{array}{l}\text { IFRS are adopted by all Kuwaiti companies listed on the Stock } \\
\text { Exchange }\end{array}$ & 4.15 & 4.00 & 0.78 & 2.00 & 5.00 & 3 \\
\hline $\begin{array}{l}\text { Develop my academic knowledge to catch up with latest } \\
\text { developments in the subject of IFRS }\end{array}$ & 4.09 & 4.00 & 0.83 & 2.00 & 5.00 & 5 \\
\hline Assists in preparing and qualifying me for future careers & 4.13 & 4.00 & 0.83 & 1.00 & 5.00 & 4 \\
\hline Assist in finding a job in one of the big companies in the future & 4.20 & 4.00 & 0.85 & 1.00 & 5.00 & 2 \\
\hline Assist me in proceeding in my graduate studies & 4.22 & 4.00 & 0.88 & 1.00 & 5.00 & 1 \\
\hline
\end{tabular}

To spot differences among the respondents about the reasons behind studying IFRS, Kruskal Wallis test was undertaken and reported in table (6). The table shows consistency among the participants about the all reasons behind studying IFRS included in the questionnaire regardless of their age, gender, whether or not they work while studying and whether or not they intend to proceed in their studies. However, some significant difference spotted among the surveyed students on the basis of their GSC score and their GPA. This result is justified on the grounds that many of the surveyed students are pursuing a degree in business administration rather than accounting. Not all of them will look for jobs in the accounting and finance fields. Hence, their motivation to learn more about IFRS is highly associated with their future careers. Needless to say students with different performances look for courses and careers compatible with capabilities and knowledge.

Table 6. Kruskal Wallis test on difference among students about advantage of IFRS

\begin{tabular}{|c|c|c|c|c|c|c|c|c|c|c|c|c|}
\hline \multirow[t]{2}{*}{ Reasons } & \multicolumn{2}{|l|}{ Age } & \multicolumn{2}{|c|}{ Gender } & \multicolumn{2}{|c|}{ GSC Score } & \multicolumn{2}{|l|}{ GPA } & \multicolumn{2}{|c|}{$\begin{array}{l}\text { Work while } \\
\text { studying }\end{array}$} & \multicolumn{2}{|c|}{$\begin{array}{l}\text { Proceed in } \\
\text { your studies }\end{array}$} \\
\hline & $\mathrm{X}^{2}$ & Sig. & $\mathrm{X}^{2}$ & Sig. & $X^{2}$ & Sig. & $\mathrm{X}^{2}$ & Sig. & $\mathrm{X}^{2}$ & Sig. & $\mathrm{X}^{2}$ & Sig. \\
\hline $\begin{array}{l}\text { IFRS are adopted by all Kuwaiti companies } \\
\text { listed on the Stock Exchange }\end{array}$ & 0.94 & 0.33 & 0.94 & 0.16 & $\underline{12.38}$ & $\underline{0.01}$ & 5.87 & 0.21 & 0.00 & 0.97 & 0.05 & 0.82 \\
\hline $\begin{array}{l}\text { Develop my academic knowledge to catch up } \\
\text { with latest developments in the subject of } \\
\text { IFRS }\end{array}$ & 0.16 & 0.69 & 0.33 & 0.69 & 6.81 & 0.15 & $\underline{11.27}$ & $\underline{0.02}$ & 0.13 & 0.72 & 2.48 & 0.12 \\
\hline $\begin{array}{l}\text { Assists in preparing and qualifying me for } \\
\text { future careers }\end{array}$ & 0.42 & 0.52 & 0.94 & 0.16 & 13.03 & 0.01 & $\underline{8.22}$ & $\underline{0.08}$ & 0.01 & 0.90 & 0.04 & 0.85 \\
\hline $\begin{array}{l}\text { Assist in finding a job in one of the big } \\
\text { companies in the future }\end{array}$ & 0.08 & 0.78 & 0.33 & 0.69 & 5.09 & 0.28 & $\underline{8.15}$ & $\underline{0.09}$ & 2.39 & 0.12 & 1.09 & 0.30 \\
\hline $\begin{array}{l}\text { Assist me in proceeding in my graduate } \\
\text { studies }\end{array}$ & 0.19 & 0.66 & 0.94 & 0.16 & 4.64 & 0.33 & 2.95 & 0.57 & 1.62 & 0.20 & 4.26 & 0.04 \\
\hline
\end{tabular}

\section{Conclusion}

In this study, the attempt has been made to explore the perceptions of a sample of Kuwaiti business administration students about their knowledge, interest, importance and reasons for learning IFRS. 350 students enrolled in colleges of business administration in Kuwait were invited to take part in a questionnaire survey. 246 students returned the questionnaires; out of the 246 questionnaires, only 228 questionnaires were answered properly. This resulted in $65 \%$ a usable response rate. $77 \%$ of the students who took part in survey aged between 20 - 23 years old, $88 \%$ of them are single and $57 \%$ are males. A significant proportion (81\%) of the respondents achieved between $61-80 \%$ in the General Secondary Examination and they are fairly distributed among different categories of their last academic semester GPA. Hence, it's fair to say that the sampled respondents reflect the population of the students studying business administration in Kuwait. This grants credibility to the findings of the study and permits generalization about Kuwaiti business students' opinion about different aspects of IFRS.

The results of the analysis revealed that the surveyed students gained knowledge about IFRS through their academic program. Business administration programs in Kuwait offer information about IFRS through some accounting courses. Most of the surveyed students knew nothing about IFRS before taking an accounting course that addresses the IFRS. They became motivated to learn more about IFRS after studying an accounting course. The surveyed students demonstrated that they acquired information about IFRS through formal academic lectures and the Internet. Yet, prefer to study more about IFRS through formal lectures and by using practical case studies applied to Kuwaiti companies. They also pointed to the use of seminars as possible means of 
learning more about IFRS. There was consensus among the participants that the business administration academic program must have more about IFRS but they preferred to be offered as elective, rather than compulsory, courses. Although Kuwait was one of the Middle Eastern countries that adopt IFAS and requested all companies listed on Kuwait Stock Exchange to comply with them, the vast majority of the students who took part in survey indicated that they were not aware of this reality. This gives clear indication that the financial reporting courses offered in the business administration programs in Kuwait are theoretical and there is a need to develop teaching methods in the program to include case studies applicable to Kuwaiti companies listed on the national stock exchange.

The respondents believe that IFRS are of paramount importance in accounting measurements and disclosure (recording business financial transactions, preparing a report about corporate performance and financial position, preparing final financial statements and in comparing performance and financial positions of different companies). They, however, assigned less level of importance to how the financial reports, prepared and presented on the basis of IFRS, used to conduct analysis or in managerial decisions.

The respondents believe studying IFRS will benefit them when they proceed in their studies and support them in finding decent jobs in the future. They further think studying IFRS assist them in finding a job in Kuwaiti listed companies since they adopt IFRS. In other words, good knowledge of IFRS is crucial to the development of the students' future career.

\section{References}

Abedana, V., Omane-Antwi, K., \& Oppong, M. (2016). Adoption of IFRS / IAS in Ghana: Impact on the quality of corporate financial reporting and related corporate tax burden. Research Journal of Finance and Accounting, 7(8), 10-25.

Al Mutawaa, A., \& Hewaidy, A. (2010). Disclosure level and compliance with IFRSs: An empirical investigation of Kuwaiti companies. International Business \& Economics Research Journal, 9(5), 33-50. https://doi.org/10.19030/iber.v9i5.566

Alsaqqa, I., \& Sawan, N. (2013). The advantages and the challenges of adopting IFRS into UAE stock market. International Journal of Business and Management, 8(9), 1-23. https://doi.org/10.5539/ijbm.v8n19p1

Alsuhaibania, A. (2012). The expected impact of IFRS adoption on Saudi Arabia based on lessons from other countries: A focus on the telecommunication business. Procedia - Social and Behavioral Sciences, 62, 1190-1198. https://doi.org/10.1016/j.sbspro.2012.09.204

Athma, P., \& Rajyalaxmi, N. (2013). Accounting Standards in India: Adoption of IFRS. Journal of Commerce \& Accounting Research, 2(2), 39-45

Balsari, C., \& Varan, S. (2014). IFRS implementation and studies in Turkey. Accounting and Management Information Systems, 13(2), 373-399

Beverley J., Bryan, H., \& Riccardo, N., (2012). Some implications of IFRS adoption for accounting education. Australian Accounting Review, 63(22), 331-340

Beverley, J. (2013). Global adoption of international financial reporting standards: Implications for accounting education. Issues in Accounting Education, 28(2), 209-220. https://doi.org/10.2308/iace-50391

Bhargava, V., \& Shikha, D. (2013). The impact of International financial Reporting standards and financial statements and ratios. The International Journal of Management, 2(2), 1-15

Bodle, K., Cybinski, P., \& Monem, R. (2016). Effect of IFRS adoption on financial reporting quality Evidence from bankruptcy prediction. Accounting Research Journal, 29(3), 292-312. https://doi.org/10.1108/ARJ-03-2014-0029

Carvalho, L., \& Bruno M. (2013). Adoption of IFRS in Brazil and the consequences to accounting education. Issues in Accounting Education, 28(2), 235-242. https://doi.org/10.2308/iace-50373

Chebaane, S., \& Othman, H. (2013). Does the adoption of IFRS influence earnings management towards small positive profits? Evidence from emerging markets. International Journal of Social, Behavioral, Educational, Economic, Business and Industrial Engineering, 7(6), 1407-1413.

Christopher S., Mary E., Alan D., \& Edward, J. (2010). Market Reaction to the Adoption of IFRS in Europe. The Accounting Review, 85(1), 31-61. https://doi.org/10.2308/accr.2010.85.1.31

Djatej, A., Zhou, D., Gorton, D., \& McGonigle, W. (2012) Critical factors of IFRS adoption in the US: an empirical study. Journal of Finance and Accountancy, 9(March), 1-14 
Dritsas, S., \& Petrakos, G. (2014). Historical financial information: An empirical study on the first time adoption of IFRS in Greece. International Business Research, 7(8), 47-58. https://doi.org/10.5539/ibr.v7n8p47

Hanefah, H., \& Singh, J. (2012) Convergence towards IFRS in Malaysia, issues, challenges and opportunities. International Journal of Business, Economics and Law, 1(December), 43-47

Helen, W., \& Kh, W. (2013). An empirical study - Adoption of International Financial Reporting Standards (IFRS) in Hong Kong education. Journal of Management Research, 5(4), 98-107. https://doi.org/10.5296/jmr.v5i4.4256

Herbert, W., \& Tsegba, I. (2013). Economic consequences of International Financial Reporting Standards (IFRS) adoption: Evidence from a developing country. European Journal of Business and Management, 5(28), 80-99.

Herbert, W., Tsegba, I., Ohanele, A., \& Anyahara, I. (2013). Adoption of International Financial Reporting Standards (IFRS), Insights from Nigerian academics and practitioners. Research Journal of Finance and Accounting, 4(6), 121-135.

Hossain, K., Niaz, A., \& Moudud-Ul-Huq, S. (2015a). The application and disclosures of IASs \& IFRSs by the DSE listed companies of Bangladesh. World Journal of Social Sciences, 5(3), 157-175.

Hossain, M., Hasan, M., \& Safiuddin, M. (2015b). Adoption of International Financial Reporting Standards in Bangladesh: Benefits and challenges. IOSR Journal of Business and Management, 17(8), 16-24.

IFRS Foundation, (2016). IFRS Application around the World: Jurisdictional Profile: Kuwait. Available at http://www.ifrs.org/Use-around-the-world/Documents/Jurisdiction-profiles/Kuwait-IFRS-Profile.pdf

Ikpefan, O., \& Akande, A. (2012). International Financial Reporting Standard (IFRS): Benefits, Obstacles and Intrigues for Implementation in Nigeria. Business Intelligence Journal, 5(2), 299-307.

Joos, Ph., \& Leung, E. (2013). Investor perceptions of potential IFRS adoption in the United States. The Accounting Review, 88(2), 577-609. https://doi.org/10.2308/accr-50338

Kenneth, N., Mastilak, C., Christopher, D., \& Joyce S. (2015). Concepts-Based Education in a Rules-Based World: A Challenge for Accounting Educators. Issues in Accounting Education, 30(4), 251-274. https://doi.org/10.2308/iace-51162

Kılıça, M., Uyar, A., \& Ataman, B. (2014). Preparedness for and perception of IFRS for SMEs: evidence from Turkey. Accounting and Management Information Systems, 13(3), 492-519.

Kim, I., \& Chung, Y. (2008). A study on Improvement of Accounting Curriculum in Commercial Information High School by Introducing K-IFRS. The Korean Research Association for the Business Education, 22.

Larson, R., \& Brady, T. (2009). Incorporating IFRS into the Accounting Curriculum. Strategic Finance, 90(8), $23-25$.

Madawaki, A. (2012). Adoption of International Financial Reporting Standards in Developing Countries: The Case of Nigeria. International Journal of Business and Management, 7(3), 152-162. https://doi.org/10.5539/ijbm.v7n3p152

Mardini, Gh., \& Almujamed, H. (2015). The adoption of IFRS 8: The case of Qatari listed companies. International Journal of Managerial and Financial Accounting, 7(3/4), 173-197. https://doi.org/10.1504/IJMFA.2015.074898

Mensah, B. (2013). Adoption of International Financial Reporting Standards (IFRS) in Ghana and the Quality of Financial Statement Disclosures. International Journal of Accounting and Financial Reporting, 3(2), 269-286. https://doi.org/10.5296/ijafr.v3i2.4489

Moqbel, M., \& Bakay, A. (2010). Are US Academics and Professionals Ready for IFRS? Working paper.

Munter, P., \& Rocker, P. (2009). IFRS and collegiate accounting curricula in the United States: 2008. A survey of the current state of education conducted by KMPG and the education committee of the American Accounting Association. Issues in Accounting Education, 24(2), 131-139. https://doi.org/10.2308/iace.2009.24.2.131

Naghshbandi, N., Ombati, R., \& Khosravi, V. (2016). Empirical study of the impact of culture on accounting practices: does it disappear after the introduction IFRS?. International Journal for Research in Business, Management and Accounting, 2(3), 108-120.

Nilsen, K. (2008). On the Verge of an Accounting Revolution: How IFRS is Affecting Accounting Education. 
Journal of Accountancy, December $1 . \quad$ Available at: http:/www.journalofaccountancy.com/issues/2008/dec/onthevergeofanacademicrevolution.html

Odia, J., \& Ogiedu, K. (2013). IFRS Adoption: Issues, Challenges and Lessons for Nigeria and other Adopters. Mediterranean Journal of Social Sciences, 4(3), 389-399. https://doi.org/10.5901/mjss.2013.v4n3p389

Okunbor, J., \& Arowoshegbe, A. (2014). Stakeholders' Perception of the Implementation of International Financial Reporting Standards (IFRS) in Nigeria. Accounting and Finance Research, 3(1), 67-72. https://doi.org/10.5430/afr.v3n1p67

Papadatos, K., \& Bellas, A. (2011). Applying IFRS Mandatory: Evidence from Greek Listed Companies. European Research Studies, 14(4), 71-96.

Patro, A., \& Gupta, V. (2012). Adoption of International Financial Reporting Standards (IFRS) in Accounting Curriculum in India - An Empirical Study. Procedia Economics and Finance, 2, 227-236. https://doi.org/10.1016/S2212-5671(12)00083-4

Paul, A., \& Burks, E. (2010), Preparing for International Financial reporting Standards. Journal of Finance and Accountancy, 4(3), 1-8.

Paul, M., \& Philip, M. (2010). Uncertainties and budget shortfalls hamper curriculum progress on IFRS. Issues in Accounting Education, 25(2), 189-198. https://doi.org/10.2308/iace.2010.25.2.189

Phan, D., Mascitelli, B., \& Barut, M. (2014). Perceptions towards International Financial Reporting Standards (IFRS): The Case of Vietnam. Global Review of Accounting and Finance, 5(1), 132-152. https://doi.org/10.21102/graf.2014.03.51.08

Ramanna, K., \& Sletten, E. (2009). Why do countries adopt International Financial Reporting Standards?. Working Paper 09-102m. https://doi.org/10.2139/ssrn.1460763

Sarea, A., \& Al Nesuf, H. (2013). The impact of management structure and bank characteristics on the level of compliance with IAS 21: Evidence from Bahrain. International Journal of Accounting and Taxation, 1(1), 58-68.

Sidik, M., \& Abd Rahim, R. (2012). The benefits and challenges of financial reporting standards in Malaysia: accounting practitioners' perceptions. Australian Journal of Basic and Applied Sciences, 6(7), 98-108.

Stephen, A., \& Schmulian, A. (2013). The effect of IFRS adoption on financial reporting pedagogy in South Africa. Issues in Accounting Education, 28(2), 243-251. https://doi.org/10.2308/iace-50386

Steven, Y., \& Yachang, Z. (2015). Accounting comparability and the accuracy of peer-based valuation models. The Accounting Review, 90(6), 2571-2601. https://doi.org/10.2308/accr-51053

Teller, R. (2009). First-time adoption of IFRS, managerial incentives, and value-relevance: Some French evidence. Journal of International Accounting Research, 8(2), 1-22. https://doi.org/10.2308/jiar.2009.8.2.1

Vinayagamoorthy, A. (2014). Opportunities challenges in adopting IFRS in India. International Journal of Business and Administration Research Review, 2(3), 132-136.

Zakari, M. (2014). Challenges of International Financial Reporting Standards (IFRS) Adoption in Libya. International Journal of Accounting and Financial Reporting, 4(2), 390-412. https://doi.org/10.5296/ijafr.v4i2.6302

Zhu, K., Alfred R., \& Jason, C. (2011). User-oriented IFRS education in introductory accounting at U.S. academic institutions: Current status and influencing factors. Issues in Accounting Education, 26(4), 725-750. https://doi.org/10.2308/iace-50058

\section{Copyrights}

Copyright for this article is retained by the author(s), with first publication rights granted to the journal.

This is an open-access article distributed under the terms and conditions of the Creative Commons Attribution license (http://creativecommons.org/licenses/by/4.0/). 